From the Department of Clinical Veterinary Medicine, Hautjärvi and Helsinki, College of Veterinary Medicine, Helsinki, Finland.

\title{
Milk Plasmin, Antitrypsin, N-Acetyl- $\beta$-D- Glucosaminidase and Bacterial Growth in Lactoserum during the Early Post Partum Period
}

\author{
By Satu Pyörälä and Liisa Kaartinen
}

\begin{abstract}
Pyörälä, S. and L. Kaartinen: Milk plasmin, antitrypsin, N-acetyl- $\beta-D$-glucosaminidase and bacterial growth in lactoserum during the early post partum period. Acta vet. scand. 1988, 29, 145-150. - The activities of plasmin, N-acetyl$\beta$-d-glucosaminidase (NAGase) and antitrypsin in milk were determined during 1 week post partum. The concentration of NAGase and antitrypsin in milk decreased significantly during this period. A slight decrease in plasmin activity was also seen. Replication rates of E. coli and S. aureus in lactoserum were also determined. Both test bacteria showed a tendency for increasing growth rates towards the end of the period. Growth of E. coli was significantly ( $p<0.01$ ) enhanced in day 2 samples as compared with samples collected during the first day post partum.
\end{abstract}

cow; lactation; milk enzymes; S. aureus; E. coli.

\section{Introduction}

The composition of colostrum differs greatly from that of mature milk. The colostrum of the cow contains more mineral salts and protein and less lactose than normal milk (Parrish et al. 1950, Jenness 1986). The major proportion of proteins in colostrum is formed by immunoglobulins. This is due to the fact that the cow transfers passive immunity to the neonate via its colostrum. The increased permeability between milk and blood compartments causes leakage of small molecular weight plasma proteins, such as $\alpha_{1}$-antitrypsin and bovine serum albumin into the milk. The high colostral antitrypsin activity is followed by a rapid decrease in activity in the first few days after calving (Sandholm \& Honkanen-Buzalski 1979). The colostrum is known to contain a high number of somatic cells (SCC); this number then decreases for the next two weeks post partum (Blackburn 1966, Cullen 1968).

Recently, the milk content of the lysosomal enzyme $\mathrm{N}$-acetyl- $\beta$-D-glucosaminidase (NAGase) during the peripartum period has been studied. Milk enzyme concentration declined rapidly in the first few days after calving and then gradually through the following four weeks (Timms \& Schultz 1985). Both NAGase and antitrypsin have been shown to assist in the diagnosis of subclinical mastitis as indicators of inflammation (Mattila et al. 1986a). To these indicators belongs also plasmin, a proteolytic enzyme, which digests fibrin, the natural substrate for plasmin. Besides fibrin, $\beta$ casein has been seen to be a good substrate for plasmin (Barry \& Donnelly 1981). Proteolytic splitting of casein seems to improve 
its quality as growth medium for bacteria, which might be a factor tilting the hostmicrobe balance in favour of mastitis pathogens in mastitis (Kaartinen \& Sandholm 1986).

Differences between bacterial growth in vitro in milk and in colostrum have been found by some authors (Dutt et al. 1986, Oliver \& Bushe 1986, Marshall et al. 1986). Infection rates are known to be high in the immediate post partum period. There is currently interest in the identity of the factors responsible for lower resistance to infection observed during this period.

The purpose of the present study was to determine replication rates of mastitis pathogens in lactoserum collected during the early post partum period and to relate this with the milk levels of three inflammatory parameters, NAGase, antitrypsin and plasmin.

\section{Materials and methods}

Quarters from 9 Finnish Ayrshire cows were selected for the experiment. The samples from 2 quarters were excluded because of a present infection. Two of the cows were in their first lactation and the others had calved 2-6 times.

Milk samples were collected daily before morning milking during a seven-day period after calving (day 1 = calving day). On the first day milk was cultured using standard bacteriological procedures according the guidelines set down by the International Dairy Federation (IDF 1981).

Milk plasmin was determined using a fluorogenic coumaryl peptide substrate as described by Richardson \& Pearce (1981), but on a microscale (Mattila et al. 1986b). The sample $(300 \mu \mathrm{l})$ was mixed with $100 \mu \mathrm{l} 0.4$ $\mathrm{mol} / \mathrm{l}$ trisodium citrate to dissociate casein micelles and to release the casein-bound plasmin. After centrifugation $(10,000 \times \mathrm{g}, 2$ min) fat was removed and a $20 \mu \mathrm{l}$ aliquot was mixed with $220 \mu \mathrm{l}$ of $0.05 \mathrm{~mol} / \mathrm{l}$ Tris$\mathrm{HCl}$ buffer, $\mathrm{pH}$ 7.4. To start the indicator reaction, $60 \mu \mathrm{l}$ of substrate $(1 \mathrm{~mol} / 1 \mathrm{~N}$-succinyl-L-alanyl-L-phenylalanyl-L-lysyl-6-

amino-4-methyl-coumarine, Serva No. 51156) was added. The plate was incubated at room temperature for $30 \mathrm{~min}$ and measured using a Fluoroskan fluorometer (Eflab, Helsinki) immediately after addition of the substrate and $30 \mathrm{~min}$ later.

NAGase was determined using the fluorometric method described by Kitchen (1978) with a commercially available kit (Milk NAGase Test, Eflab) (Mattila \& Sandholm 1985) Trypsin-inhibitor capacity (antitrypsin) was measured using the Milk Antitrypsin Test (Eflab) (Sandholm et al. 1984, Mattila \& Sandholm 1985).

Bacterial growth in milk lactoserum was investigated by microturbidometry. Strains of Escherichia coli and Staphylococcus aureus were used, both originating from clinical cases of mastitis. Milk lactoserum (100 $\mu \mathrm{l})$ prepared from skimmed milk by highspeed centrifugation $(20000 \mathrm{~g}, 60 \mathrm{~min},+$ $4^{\circ} \mathrm{C}$ ) was diluted with $100 \mu \mathrm{l} 0.9 \%$ saline and inoculated with $50 \mu \mathrm{l}$ of bacterial suspension in $0.9 \%$ saline $\left(10^{7} \mathrm{CFU} / \mathrm{ml}\right)$. Samples were incubated for $20 \mathrm{~h}$ at $+37^{\circ} \mathrm{C}$ and shaken for $15 \mathrm{~min}$ hourly. The increase in turbidity was measured at $620 \mathrm{~nm}$ once per hour with a Multiskan MCC (Labsystems, Helsinki). The analyser was interfaced to a micro-computer to calculate delta absorbances, store them and draw the growth curves. The generation time for test bacteria in each sample was defined from the tangent of the growth curve at the logarithmic phase (Mattila et al. 1986b).

A kinetic analysis of the decrease in milk levels of the indicators (NAGase, antitrypsin) was carried out using the least squares fitting method for a two-compartment firstorder kinetic model. Mann-Whitney and 
Kruskall-Wallis tests (STSC 1986) were used in the statistical analysis.

\section{Results}

No significant differences between days were seen in terms of milk plasmin activity. However, there was a slight tendency towards a decrease in activity during the last days. Both NAGase and antitrypsin activities decreased gradually after parturition (Fig. 1). the decrease was statistically significant between days 1 and 2, and days 2 and 3 ( $p<0.01$ ). the half-lives of both activities were about the same, NAGase 9.0 and antitrypsin $8.4 \mathrm{~h}$.

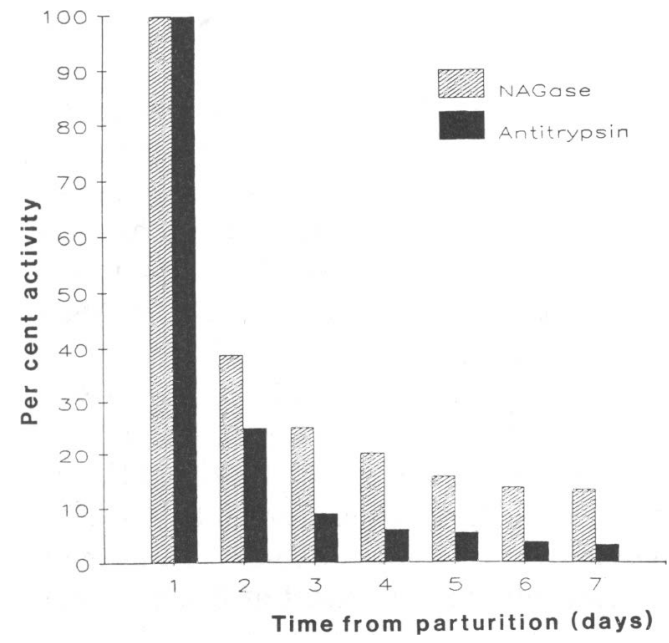

Figure 1. Relative decrease in N-acetyl- $\beta$-Dglucosaminidase and antitrypsin in milk samples collected after parturition.

In the bacterial growth studies both E. coli and $S$. aureus showed low growth rates just after parturition, as indicated by longer generation times of both test bacteria. The replications rates increased gradually during the follow-up period, but the only significant difference found was in the growth of E. coli between days 2 and 2 ( $p<0.01$ ). Fig. 2

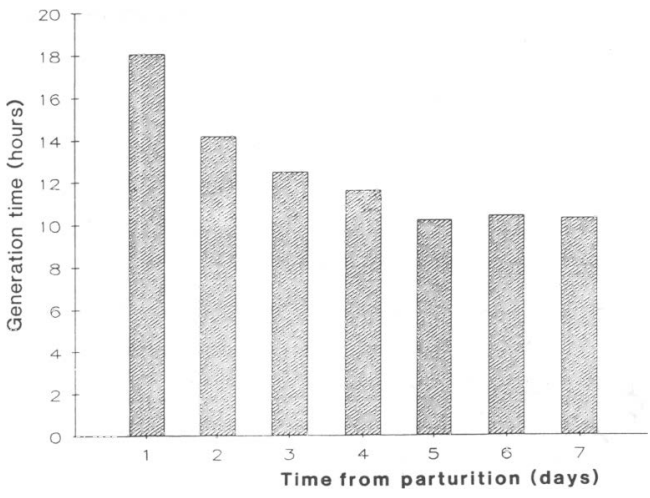

Figure 2. Mean generation time of Escherichia coli in lactoserum collected through 1 week post partum.

shows the mean generation times of E. coli for consecutive days post partum.

\section{Discussion}

Higher milk plasmin activities have been recorded in the first lactation month than in milk from later lactation (Mattila et al. 1986b). In the present study no clear differences were seen in milk plasmin content between the days of the first week after calving. Blood plasma is rich in plasminogen, the inactive precursor of plasmin. Schaar \& Funke (1986) found higher plasminogen and plasmin concentrations in milk samples taken from inflammed quarters than in normal milk. Plasminogen requires activation by specific activators to become the active protease plasmin. Activation is determined by the activator/inhibitor balance and by plasmin inhibitors. This study did not reveal any significant difference between colostrum and milk in this respect.

Our results on NAGase activity in milk during consecutive days after calving agreed with those of Timms \& Schultz (1985). NAGase activity was highest on day 1 , and a rapid fall was seen thereafter. On day 7 post partum the levels were still higher than the 
mean milk level recorded in later lactation (Mattila et al. 1986a).

Milk antitrypsin activity decreased gradually during the first week after parturition, as also reported by Honkanen-Buzalski \& Sandholm (1981). In colostrum, antitrypsin is strongly affected by the presence of colostral trypsin inhibitor and by the increase in vascular permeability in the udder. The function of colostral inhibitors is to protect immunoglobulins from proteolytic damage during the colostral-intestinal transfusion to the newborn.

The generation times of pathogens in vitro have been shown to be shorter in early lactation and decrease again uniformly towards late lactation (Mattila et al. 1986b). In the present material, bacterial generation times in vitro were longer on day 1 than on the following days. Consequently, lactoserum from the days towards the end of the first week would seem to be a better growth medium for bacteria. The level to which generation times of E. coli declined on day 7 was somewhat lower than the mean level recorded in the first month (Mattila et al. 1986b). The growth rate on day 1 was lower than the mean level during mid-lactation, indicating a slight growth inhibitory effect in colostrum.

It is well known that mastitic infections caused by gram positive bacteria may persist within the mammary gland from one lactation period to another, while infections caused by gram negative bacteria may not. This can be predicted by in vitro growth of various strains of bacteria in dry cow secretions. Reports concerning bacterial in vitro growth rates in lacteal secretions collected during different stages of lactation seem therefore to be conflicting. Our results from bacterial growth studies with E. coli agreed with those of Oliver \& Bushe (1986), who found a growth inhibition of E. coli and K. pneumo- niae especially during the dry period, but also at parturition. One week later the growth was clearly enhanced. According to Dutt et al. (1986), the in vitro growth of E. coli was generally higher in milk than in secretions of the dry period, but again significantly lower on calving day than 2 weeks later. The same difference was seen in the growth of Streptococcus uberis, but at a non-significant level. Opposite results were obtained in a study on in vitro growth of streptococci in mammary secretions: all strains examined grew better on calving day than on day 7 post partum (Todhunter et al. 1985).

Colostrum and mastitic milk have some similar properties. The levels of inflammatory markers are high both in colostrum and mastitic milk, though in colostrum bacterial growth seems to be concomitantly inhibited. Mastitic milk and whey have been shown to support bacterial growth in vitro and bacterial replication rates to have a strong positive correlation with concentrations of inflammatory markers in the milk. It has been suggested that casein degradation products contribute as bacterial nutrients to the enhanced growth in mastitic milk (Mattila et al. 1986b). One growth limiting factor for bacteria may be the lack of a suitable nitrogenous substrate due to the low proteinase contents of milk. As the amount of active plasmin in colostrum was even slightly higher than later, this explanation for lower replication rates seen on day 1 is not likely. At parturition the mammary gland secretion contains high concentrations of immunoglobulins, various bacteriostatic nonspecific agents and a great number of leucocytes (Reiter 1978). These features are also found to some extent in mastitic milk. The lower growth rate of bacteria in colostrum may be due to complement-mediated bacterial activity; however, no really marked growth in- 
hibition was seen. It is well known that cows are highly susceptible to mastitis during the peripartum period. Despite its high potential at that time, the defence system of the gland seems to be less able to prevent mastitis.

As regards the bacterial growth studies, this study is merely preliminary. It would be of interest to complement bacterial growth studies with more species of bacteria during a longer follow-up period.

\section{References}

Barry JG, Donelly WJ: Casein compositional studies. II. The effect of secretory disturbance on casein composition in freshly drawn and aged bovine milks. J. Dairy Res. 1981, 48, 437-446.

Blackburn PS: The variation in the cell count of cow's milk throughout lactation and from one lactation to the next. J. Dairy Res. 1966, 33, 193-198.

Cullen GA: Cell count throughout lactation. Physiological variation in the cell count of cow's milk during lactation. Vet. Rec. 1968, 83, 125128.

Dutt $K W$, Eberhart $R J$, Wilson RA: In vitro growth of mastitis pathogens of the dry and peripartum periods. J. Dairy Sci. 1986, 69, 2408-2415.

Honkanen-Buzalski T, Sandholm M: Trypsin-inhibitors in mastitic milk and colostrum: correlation between trypsin-inhibitor capacity, bovine serum albumin and somatic cell contents. J. Dairy Res. 1981, 48, 213-223.

International Dairy Federation: Isolation and identification of mastitis bacteria. IDF document 1981, 132, 19-27.

Jenness R: Biochemical and nutritional aspects of milk and colostrum. In: B. L. Larson (ed.), Lactation. The Iowa State University Press, Ames, Iowa 1985, pp. 164-197.

Kaartinen L, Sandholm M: Regulation of plasmin activation in mastitic milk. Correlation with inflammatory markers and growth of Streptococcus agalactiae. J. Vet. Med. B 1986, 34, 42 -50 .

Kitchen, B-J, Middleston G, Salmon M: Bovine milk $\mathrm{N}$-acetyl- $\beta$-D-glukosaminidase and its significance in the detection of abnormal udder secretions. J. Dairy. Res. 1978, 45, 10-15.

Marshall VME, Cole WM, Bramley AJ: Influence of the lactoperoxidase system on susceptibility of the udder to Streptococcus uberis infection. J. Dairy Res. 1986, 53, 507-514.

Mattila T, Pyörälä S, Sandholm M: Comparison of milk antitrypsin, albumin, N-acetyl- $\beta$-Dglukosaminidase, somatic cells and bacteriological analysis as indicators of bovine subclinical mastitis. Vet. Res. Comm. 1986a, 10, 113 -124 .

Mattila T, Sandholm M: Milk plasmin, N-acetyl$\beta$-D-glucosaminidase and antitrypsin as determinants of bacterial replication rates in whey. J. Dairy Sci. 1986, 69, 670-675.

Mattila T, Syväjärvi J, Sandholm M: Bacterial growth in whey from mastitic and nonmastitic quarters. Amer. J. vet. Res. 1984, 45, 2504 2506.

Mattila T, Syväjärvi J, Sandholm M: Milk antitrypsin, NAGase, plasmin and bacterial replication rate in whey - Effects of lactation stage, parity and daily milk yield. J. Vet. Med. B. 1986b, 33, 462-470.

Mattila T, Sandholm M: Antitrypsin and N-acetyl- $\beta$-D-glucosaminidase as markers of mastitis in a herd of Ayrshire cows. Amer. J. vet. Res. 1985, 46, 2453-2456.

Oliver SP, Bushe T: Inhibition of coliform mastitis pathogen growth during involution of the bovine mammary gland. Proceedings of Symposium on Mastitis Control and Hygienic Production of Milk, Espoo, Finland, June 10-12, 1986, p. 25-30.

Parrish DB, Wise GH, Hughes JS, Atkeson FW: Properties of the colostrum of the dairy cow. V. Yield, specific gravity and concentrations of total solids and its various components of colostrum and early milk. J. Dairy Sci. 1950, 33, 457-465.

Reiter B: Review of the progress of Dairy Science: antimicrobial systems in milk. J. Dairy Res. 1978, 45, 131-147.

Richardson $B C$, Pearce $K N$ : The determination of plasmin in dairy products. New Zealand $\mathrm{J}$. Dairy Sci. Technol. 1981, 16, 209-220. 
Sandholm M, Honkanen-Buzalski T: Colostral trypsin-inhibitor capacity in different animal species. Acta vet. scand. 1979, 20, 469-476.

Sandholm M, Honkanen-Buzalski T, Kangasniemi $R$ : Milk trypsin-inhibitor capacity as an inhibitor of bovine mastitis - a novel principle which can be automated. J. Dairy Res. 1984, 51, 1-9.

Schaar J, Funke H: Effect of subclinical mastitis on milk plasminogen and plasmin compared with that on sodium, antitrypsin and $\mathrm{N}$-acetyl$\beta$-D-glucosaminidase. J. Dairy Res. 1986, 53, 515-528.

STSC, Inc.:Statgraphics ${ }^{\mathrm{R}}$ Statistical Graphics System, Rockville, Maryland, USA 1986.

Timms LL, Schultz LH: N-acetyl- $\beta$-D-glucosaminidase in milk and blood plasma during dry and early postpartum periods. J. Dairy Sci. 1985, 68, 3367-3370.

Todhunter DA, Smith KL, Schoenberger PS: In vitro growth of mastitis associated streptococci in bovine mammary secretions. J. Dairy Sci. $1985,68,2337-2346$.

(Received September 28, 1987).

Reprints may be requested from: Satu Pyörälä, SF-04840 Hautjärvi, Finland.

\begin{abstract}
Sammanfattning
Mjölk plasmin, antitrypsin, $N$-acetyl- $\beta-D$ glucosaminidase och bakterietillväxt i lactoserum den första perioden postpartum.

Aktiviteten av plasmin, $\mathrm{N}$-acetyl- $\beta$-D-glucosaminidase (NAGase) och antitrypsin i mjölk bestämdes under 1 vecka efter kalvningen. Mjölkkoncentrationen av NAGase och antitrypsin minskade signifikant under denna period. En liten minskning i plasminaktiviteten kunde också ses. Replikationsgraden av E. coli och S. aureus i laktoserum bestämdes även. Båda testbakterierna visade en tendens till ökad replikation mot slutet av perioden. Tillväxten av E. coli var signifikant ( $p<0.01$ ) förhöjd $\mathrm{i}$ proven från dag 2 jämfört med proven som togs den första dagen postpartum.
\end{abstract}

